\title{
Defoliation heights for palisade grass cv. Marandu in silvopastoral system
}

\author{
[Alturas de desfolhação para capim-marandu em sistema silvipastoril] \\ V.A.V. Oliveira ${ }^{1}$, T.G.S. Braz ${ }^{2}$, R.B. Silva ${ }^{1}$, A.C.R. Veloso ${ }^{1}$, L.D.A. Rufino ${ }^{3}$, \\ J.A. Martuscello ${ }^{4}$, M.H.F. Mourthé ${ }^{2}$, L.V. Barros ${ }^{2}$ \\ ${ }^{1}$ Aluno de pós-graduação - Instituto de Ciências Agrárias - Universidade Federal de Minas Gerais - Montes Claros, MG \\ ${ }^{2}$ Instituto de Ciências Agrárias - Universidade Federal de Minas Gerais - Montes Claros, MG \\ ${ }^{3}$ Empresa de Pesquisa Agropecuária de Minas Gerais - Montes Claros, MG \\ ${ }^{4}$ Universidade Federal de São João del-Rei - São João del-Rei, MG
}

\begin{abstract}
The objective was to test the response of Urochloa brizantha cv. Marandu in monoculture and in silvopastoral system (SPS), at two distances from the trees, and define the best defoliation height for SPS. Four intermittent defoliation heights $(25,35,45$ and $55 \mathrm{~cm})$ and two distances from tree lines $(2.5$ and $5.0 \mathrm{~m})$ were evaluated in the SPS with a control defoliated with $25 \mathrm{~cm}$ in full sun. The experiment was performed in a randomized block design with 3 replicates in a $4 \times 2+1$ split plot scheme. The control had higher forage accumulation (46.9kg/ha. day) than the SPS $\left(31.1 \mathrm{~kg} / \mathrm{ha}\right.$. day). The bulk density was also higher in the control $\left(0.89 \mathrm{mg} / \mathrm{cm}^{3}\right)$ than in SPS $\left(0.48 \mathrm{mg} / \mathrm{cm}^{3}\right)$. The percentage of leaves $(78.06 \%)$ and leaf/stem ratio $(6.04)$ did not differ among the treatments. In the SPS, there was an increase of $31.07 \%$ in forage accumulation from 25 to $55 \mathrm{~cm}$. The forage accumulation and bulk density of Urochloa brizantha cv. Marandu in monoculture is greater than in the SPS regardless of the management goal and the distance from trees. The goal of $55 \mathrm{~cm}$ in the SPS presented greater forage accumulation.
\end{abstract}

Keywords: bulk density, forage accumulation, morphological composition, shading, Urochloa brizantha

\section{RESUMO}

O objetivo foi testar a resposta de pastos de Urochloa brizantha $\mathrm{cv}$. Marandu em monocultivo e em sistema silvipastoril (SSP), a diferentes distâncias das árvores, bem como definir qual altura de desfolhação é a mais indicada para manejo em SPS. Foram avaliadas quatro alturas de desfolhação intermitente (25, 35, 45 e $55 \mathrm{~cm})$ e duas distâncias das linhas de árvores (2,5 e 5,0m), no SPS, e uma testemunha desfolhada com $25 \mathrm{~cm}$, em pleno sol. $O$ delineamento foi em blocos ao acaso, com três repetições, em esquema de parcelas subdivididas $4 \times 2+$ 1. O controle apresentou maior acúmulo de forragem $(46,9 \mathrm{~kg} / \mathrm{ha}$.dia) que a média do SSP $(31,1 \mathrm{~kg} / \mathrm{ha}$.dia). A densidade volumétrica da forragem do controle $\left(0,89 \mathrm{mg} / \mathrm{cm}^{3}\right)$ foi maior que a do SSP $\left(0,48 \mathrm{mg} / \mathrm{cm}^{3}\right)$. A porcentagem de folhas $(78,06 \%)$ e a relação folha/colmo $(6,04)$ não diferiram entre os tratamentos. $O$ aumento das alturas de 25 para $55 \mathrm{~cm}$ no SSP resultou em aumento de 31,07\% no acúmulo de forragem. O acúmulo e a densidade volumétrica da forragem são maiores no monocultivo, independentemente da meta de manejo e da distância das árvores no sistema silvipastoril. A meta de $55 \mathrm{~cm}$ no silvipastoril apresenta maior acúmulo de forragem.

Palavras-chave: composição morfológica, densidade volumétrica, acúmulo de forragem, sombreamento, Urochloa brizantha

\section{INTRODUCTION}

Recently, pasture management has been the subject of constant studies. As the advances in forage research have been consolidated in Brazil, the management goals for forage in monoculture systems have become more applicable. This panorama is not valid for the study of forages in the silvopastoral system (SPS), where the goals and management that optimize the forage response in the understory are not consolidated. The SPS is an alternative for recovering degraded areas and intensifying extensive pastures. There is a growing interest of farmers and the incentives

Recebido em 29 de novembro de 2020

Aceito em 24 de fevereiro de 2021

*Autor para correspondência (corresponding author)

E-mail: thiagogsbz@hotmail.com 
for using it resulting from public policies. Therefore, there is a need for more research that seeks to determine management goals of forages intercropped with trees.

With the amount of research involving pasture management, it is possible to understand that grasses should be managed using the pre-grazing condition of $95 \%$ of light interception (LI) by the canopy. This condition is also known as critical leaf area index and corresponds to a critical height used as management goal. The height of the residue varies according to different authors, but, in general, it is defined around $50 \%$ of the pregrazing height. When reaching this point, there is a considerable decrease in forage intake (Fonseca et al., 2012). The forage plant undergoes structural and physiological changes when subjected to shading (Paciullo et al., 2007). Some changes are represented by the reduction in the specific leaf area index, increase in the elongation of stems, in the final length of leaf and increase in the chlorophyll content. These changes may modify the canopy structure and the capacity of intercepting light. So, the height with $95 \%$ of LI may change in a shaded pasture.

Thus, Urochloa brizantha cv. Marandu, the most used forage plant in Brazil (Montagner et al., 2013), is a great option for SPS. Its importance for livestock justifies the research on the response of Marandu palisade grass in SPS. Well-defined management protocols, with scientific evidence are essential for the management goals of SPS to be consolidated among farmers who will adopt the system more easily due to the positive results in the growth of forage. It is believed that changes in the physiological response to eucalyptus trees shading may influence the structure and forage accumulation and make the ideal height to manage Marandu palisade grass higher than that recommended for the full sun. Similarly, the proximity of the trees can provide more shade to the forage and modify its response pattern as well. Thus, the objective was to compare the response of Urochloa brizantha cv. Marandu in monoculture and in SPS at different distances from the trees, and to define which defoliation height is the most suitable to manage pasture in SPS.

\section{MATERIAL AND METHODS}

The experiment was carried out from 18/12/2017 to $17 / 05 / 2018$ in a SPS with approximately $6,900 \mathrm{~m}^{2}$, established 10 years ago, in the municipality of Montes Claros, at $16^{\circ} 40^{\prime} 3.17^{\prime \prime}$, south latitude, $43^{\circ} 50$ ' 40.97', west longitude, 598 meters above sea level. The climate is Aw (tropical savanna) characterized by high annual temperatures and rainfall regime marked by rainy summer and dry winter. The climate data was registered during the experimental period (Figure 1). The experiment was performed in a randomized block design with 3 replicates, in a 4 $\times 2+1$ split plot scheme. Four management goals were evaluated $(25,35,45$ and $55 \mathrm{~cm}$ of pregrazing height) at 2.5 and 5 meters of distance from the tree line.

The control was defoliated with $25 \mathrm{~cm}$. The management goals were allocated in the plots and the distances in the split plot. The control corresponds to the height of Marandu palisade grass at $95 \%$ of light interception (Giacomini et al., 2009). In all treatments, the residue height was $50 \%$ of the pre-defoliation height (Fonseca et al., 2012). So, the residual height varies according to the treatment. Residual heights of 12.5, 17.5, 22.5 and 27.5 were used for the treatments of 25,35 , 45 and $55 \mathrm{~cm}$, respectively. The forage was established about a year before the beginning of the experiment, in $9 \times 4 \mathrm{~m}$ plots, between the eucalyptus lines.

The inserted tree species (Eucalyptus sp. Clone I144) had a spacing of $10 \mathrm{~m}$ between the simple lines of trees and approximately $4 \mathrm{~m}$ between trees within the line. At the beginning of the experiment, the trees were pruned to remove the lower branches and to reduce the shade of the understory. The shading by eucalyptus trees was evaluated in the beginning of the experiment using the ceptometer AccuPARmodel LP-80. Measurements were made in the shade-free area and in the shaded area, and the level of shading provided by the trees was $50 \%$ of the photosynthetically active radiation. 


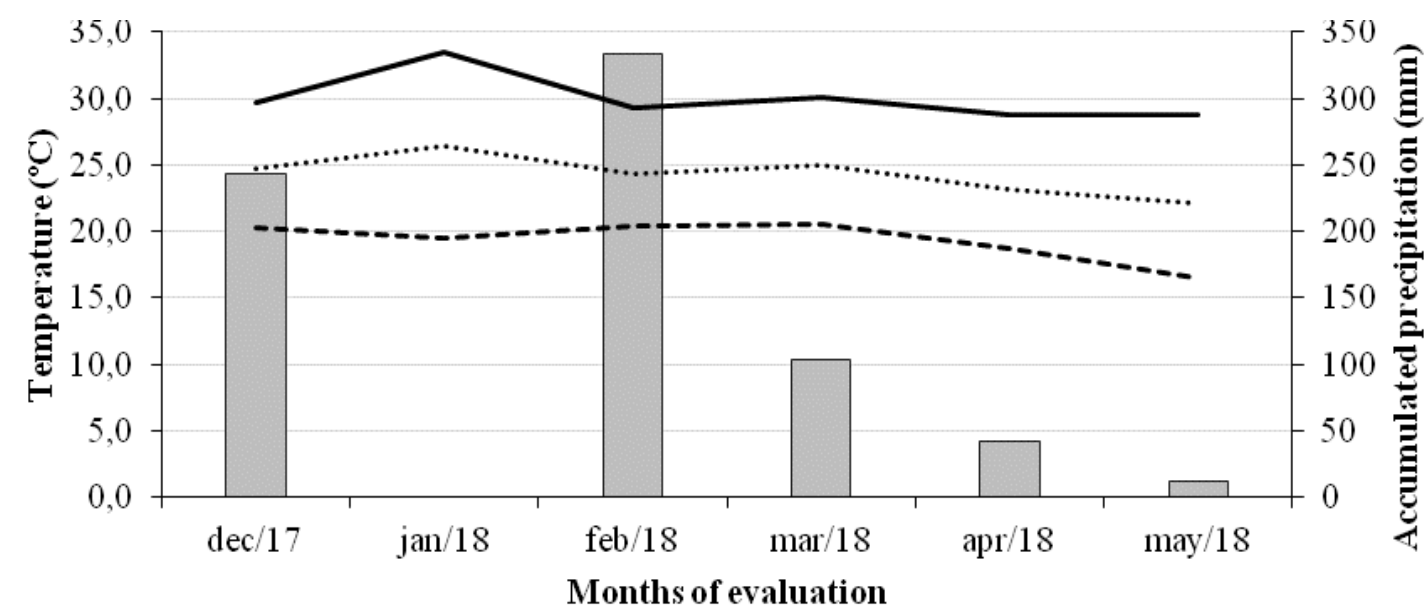

PREC —MAXT -........ AVET -----MINT

Figure 1. Temperature and monthly precipitation in Montes Claros -MG during the experimental period. Source: National Institute of Meteorology - INMET (2018).

The results of the chemical analysis of the soil at 0-20 layer were: $\mathrm{pH}_{\mathrm{H}_{2} \mathrm{O}}=5.1$; P-Mehlich $\left(\mathrm{mg} / \mathrm{dm}^{3}\right)=10.58 ; \mathrm{K}\left(\mathrm{mg} / \mathrm{dm}^{3}\right)=203 ; \mathrm{Ca}^{+2}$ $\left(\mathrm{cmol}_{\mathrm{c}} / \mathrm{dm}^{3}\right)=7.62 ; \mathrm{mg}^{+2}\left(\mathrm{cmol}_{\mathrm{c}} / \mathrm{dm}^{3}\right)=2.27 ; \mathrm{Al}^{+3}$ $\left(\mathrm{cmolc} / \mathrm{dm}^{3}\right)=0 ; \mathrm{H}+\mathrm{Al}\left(\mathrm{cmolc} / \mathrm{dm}^{3}\right)=2.45 ; \mathrm{V}$ $(\%)=81$; organic matter $(\mathrm{dag} / \mathrm{kg}): 6.28$. The pasture was fertilized with $80 \mathrm{~kg} / \mathrm{ha}$ of $\mathrm{P}_{2} \mathrm{O}_{5}$ as simple superphosphate, $100 \mathrm{~kg} / \mathrm{ha}$ of $\mathrm{K}_{2} \mathrm{O}$ as potassium chloride and $100 \mathrm{~kg} / \mathrm{ha}$ of nitrogen as urea. Fertilizers with nitrogen and potassium were applied twice, with the first after the uniform cut and the second, 60 days after the first one. The entire area was kept irrigated in the critical periods of the year using a sprinkler system at a rate of 730 L/hour for 4 hours a day.

The forages were subjected to a uniform cut in December 2017 and were subsequently managed according to the treatment heights. To define the moment of cut, the height of the plants was monitored every two days by measuring 10 random points in each plot. The evaluative cuts were made when each plot reached the height recommended by the treatments. Thus, two samples of forage per plot were collected, one at $2.5 \mathrm{~m}$ and the other at $5.0 \mathrm{~m}$ from the tree line, with a $1.0 \mathrm{~m}^{2}$ frame, positioned within the useful area (discounting $1 \mathrm{~m}$ in each side). All forage collected in the frame was weighed to determine the forage production (fresh mass production - FMP). From the total harvested, two subsamples with about $150 \mathrm{~g}$ each were taken to determine the dry matter content (\%DM) and to separate the morphological components of leaves, stems and dead material.
With the FMP and \% DM, the average production of forage per cut (APRO) was estimated. The leaf/stem ratio was determined by the quotient between the dry weight of green leaves and the dry weight of green stems. The values of forage mass measured in the frames were converted to the magnitude of $\mathrm{kg} / \mathrm{ha}$ and the morphological components (leaf, stem and dead material) expressed as proportion (\%) of the forage mass. The forage accumulation $(\mathrm{kg} / \mathrm{ha}$ day of forage mass) was calculated from the amount of forage accumulated above the height of the residue (green leaves + green stems), divided by the number of days of growth.

The production of total dry mass of the experimental period was obtained by the sum of the production of all cuts. Tiller population density was measured on the day of harvest, by counting live tillers present in a $0.5 \times 0.5 \mathrm{~m}$ frame, positioned at the assessment sites in each plot. The density of forage, expressed in $\mathrm{mg} / \mathrm{cm}^{3}$, was obtained by dividing the harvested mass above the residue height by the volume in $\mathrm{cm}^{3}$ occupied by the harvested forage. The volume was estimated based on the area of the frame and the height from the surface of the leaf horizon and the height of the residue. After sampling, the plot was completely standardized with a motorized brush cutter, according to the height of the residue of the respective treatment. 
Data were submitted to analysis of variance and the treatments (heights and distances in the SPS) were compared to the control using Dunnett's test at $5 \%$ probability. The effect of heights within the SPS was evaluated by regression, where the models were chosen based on the significance of the parameters, coefficient of determination and biological explanation. The comparison between the tree distances within the SPS was performed using the $\mathrm{F}$ test. When there was a significant interaction between heights within the SPS and distances from the trees, the interaction was decomposed. The critical level of probability was $5 \%$. All data were analyzed using the software GENES - Aplicativo Computacional em Genética e Estatística, version 1990.2017.43 (Cruz, 2013).

\section{RESULTS AND DISCUSSION}

There was difference between common treatments and the control, and effect of management heights within the silvopastoral system (SPS) for average production per cycle (APRO). The APRO of treatments with 25 and $35 \mathrm{~cm}$ in the SPS was lower than the control, regardless of the distance from the trees $(2.5$ or $5.0 \mathrm{~m})$. The APRO of treatments with 45 and $55 \mathrm{~cm}$ did not differ from the control at 2.5 and 5.0 meters apart (Table 1).

The APRO is the amount of forage harvested in each harvest. Thus, it is not able to represent the total production of the plots. It was observed that higher APRO values in the SPS were only possible managing greater heights than the ones recommended in the monoculture. In fact, there is a positive association between the height of the pasture at the time of harvest and the amount of biomass in the grazable horizon (Dim et al., 2015). The increase in pre-grazing height increases the forage mass at harvest and influences the period of occupation and the stocking rate of the pasture.

Table 1. Productive characteristics of palisade grass cv. Marandu in monoculture (Contr.) and in silvopastoral system (SPS) under 4 defoliation heights and at two distances from trees

\begin{tabular}{|c|c|c|c|c|c|c|c|}
\hline \multirow{2}{*}{ Variable } & \multirow{2}{*}{ Contr. } & \multirow{2}{*}{ Distance (m) } & \multicolumn{4}{|c|}{ management heights in SPS $(\mathrm{cm})$} & \multirow{2}{*}{$\mathrm{CV}(\%)$} \\
\hline & & & 25 & 35 & 45 & 55 & \\
\hline \multirow{2}{*}{$\operatorname{APRO}(\mathrm{kg} /$ ha.corte $)$} & \multirow{2}{*}{1312.7} & 2.5 & $501.6 a^{*}$ & $831.2 \mathrm{a}^{*}$ & $1181.3 \mathrm{a}$ & $1492.5 \mathrm{a}$ & \multirow{2}{*}{14.85} \\
\hline & & 5.0 & $644.5 a^{*}$ & $880.3 \mathrm{a}^{*}$ & $1201.8 \mathrm{a}$ & $1548.0 \mathrm{a}$ & \\
\hline \multirow{2}{*}{$\%$ LEA $(\%)$} & \multirow{2}{*}{81.97} & 2.5 & $80.15 \mathrm{a}$ & $76.24 \mathrm{a}$ & $76.13 \mathrm{a}$ & $75.75 \mathrm{a}$ & \multirow{2}{*}{6.14} \\
\hline & & 5.0 & $82.12 \mathrm{a}$ & $78.61 \mathrm{a}$ & $73.82 \mathrm{a}$ & $73.79 \mathrm{a}$ & \\
\hline \multirow{2}{*}{$\% \operatorname{STE}(\%)$} & \multirow{2}{*}{13.56} & 2.5 & $12.33 \mathrm{a}$ & $17.56 \mathrm{a}$ & $19.43 \mathrm{a}$ & $22.77 \mathrm{a}$ & \multirow{2}{*}{23.30} \\
\hline & & 5.0 & $14.15 \mathrm{a}$ & $18.46 \mathrm{a}$ & $24.28 \mathrm{a}$ & $26.01 a^{*}$ & \\
\hline \multirow{2}{*}{$\%$ DEA $(\%)$} & \multirow{2}{*}{4.46} & 2.5 & $7.51 \mathrm{a}$ & $6.20 \mathrm{a}$ & $4.44 \mathrm{a}$ & $1.47 \mathrm{a}$ & \multirow{2}{*}{58.94} \\
\hline & & 5.0 & $3.72 b$ & $2.93 \mathrm{a}$ & $1.89 \mathrm{a}$ & $0.20 \mathrm{a}$ & \\
\hline \multirow{2}{*}{ LSR } & \multirow{2}{*}{7.50} & 2.5 & $10.73 a$ & $5.81 \mathrm{a}$ & $4.46 \mathrm{a}$ & $4.90 \mathrm{a}$ & \multirow{2}{*}{34.18} \\
\hline & & 5.0 & $7.14 \mathrm{a}$ & $5.06 \mathrm{a}$ & $3.99 \mathrm{a}$ & $3.32 \mathrm{a}$ & \\
\hline \multirow{2}{*}{ TDM (kg/ha) } & \multirow{2}{*}{5992.7} & 2.5 & $2903.9 \mathrm{~b} *$ & $3599.1 a^{*}$ & $4463.2 \mathrm{a}^{*}$ & $4009.4 a^{*}$ & \multirow{2}{*}{13.33} \\
\hline & & 5.0 & $3936.5 a^{*}$ & $3789.7 a^{*}$ & $4531.7 a^{*}$ & $4281.2 \mathrm{a}^{*}$ & \\
\hline \multirow{2}{*}{ LDM (kg/ha) } & \multirow{2}{*}{4900.5} & 2.5 & $2322.8 b^{*}$ & $2710.9 a^{*}$ & $3412.2 \mathrm{a}^{*}$ & $3048.3 \mathrm{a}^{*}$ & \multirow{2}{*}{15.02} \\
\hline & & 5.0 & $3220.6 a^{*}$ & $2995.5 \mathrm{a} *$ & $3338.8 \mathrm{a}^{*}$ & 3091.9a* & \\
\hline \multirow{2}{*}{ ACCU (kg/ha.day) } & \multirow{2}{*}{46.9} & 2.5 & $22.0 b^{*}$ & $27.4 a^{*}$ & $34.9 a^{*}$ & $32.4 a^{*}$ & \multirow{2}{*}{13.08} \\
\hline & & 5.0 & $31.0 a^{*}$ & $30.0 a^{*}$ & $36.4 a^{*}$ & $34.5 a^{*}$ & \\
\hline \multirow{2}{*}{ DENS $\left(\mathrm{mg} / \mathrm{cm}^{3}\right)$} & \multirow{2}{*}{0.8863} & 2.5 & $0.3745 \mathrm{a}^{*}$ & $0.4641 a^{*}$ & $0.5034 \mathrm{a}^{*}$ & $0.5025 \mathrm{a}^{*}$ & \multirow{2}{*}{17.02} \\
\hline & & 5.0 & $0.4850 \mathrm{a}^{*}$ & $0.4919 a^{*}$ & $0.5156 a^{*}$ & $0.5242 \mathrm{a}^{*}$ & \\
\hline
\end{tabular}

*Statistically different from the control by Dunnett's test at 5\% probability; Means followed by lowercase letters in the column do not differ between the distances of 2.5 and $5.0 \mathrm{~m}$ by Tukey's test at 5\% probability; APRO: average forage production; \%LEA: percentage of leaves; \%STE: stem percentage; \%DEA: percentage of dead material; LSR: leaf/steam ratio; \% TDM: total dry mass; ACCU: forage accumulation; DENS: bulk density of forage. 
Besides that, the mass harvested with $25 \mathrm{~cm}$ in the monoculture (control) was similar to that harvested with 45 and $55 \mathrm{~cm}$ in SPS, defoliation goals that are numerically superior. This is due to the reduction in the canopy density of shaded pastures (Bernardino and Garcia, 2009; Lopes et al., 2017a), showing that in SPS Marandu grass only reaches amounts of biomass similar to monoculture in each grazing cycle, if managed in a greater height than recommended for full sun.
There was no effect of distance from the trees on the APRO that was studied in isolation in function of to the management heights in the SPS (Table 2). The APRO of Marandu grass pastures in the SPS had a linear and positive response to the increase in management heights. The use of $55 \mathrm{~cm}$ in relation to $25 \mathrm{~cm}$ in the SPS resulted in APRO $170 \%$ higher, probably due to the longer growth period and the longer harvested horizon.

Table 2. Productive characteristics of palisade grass cv. Marandu in monoculture (Contr.) and in silvopastoral system (SPS) under 4 defoliation heights

\begin{tabular}{|c|c|c|c|c|c|c|c|}
\hline \multirow{2}{*}{ Variable } & \multirow{2}{*}{ Contr. } & \multicolumn{4}{|c|}{ Management heights in SPS $(\mathrm{cm})$} & \multirow{2}{*}{ Equation } & \multirow{2}{*}{$\mathrm{R}^{2}$} \\
\hline & & 25 & 35 & 45 & 55 & & \\
\hline APRO (kg/ha) & 1312.7 & $573.1^{*}$ & $855.8^{*}$ & 1191.6 & 1520.2 & $\hat{Y}=-235.78+31.7733 x$ & 99.78 \\
\hline$\%$ LEA & 81.97 & 81.14 & 77.43 & 74.98 & 74.78 & $\hat{Y}=77.08$ & - \\
\hline$\%$ STA & 13.56 & 13.24 & 18.01 & 21.85 & $24.39 *$ & $\hat{\mathrm{Y}}=4.4577+0.3728 \mathrm{x}$ & 97.34 \\
\hline$\%$ DEA & 4.46 & 5.62 & 4.56 & 3.17 & 0.83 & $\hat{Y}=9.850-0.1576 x$ & 94.99 \\
\hline LSR & 7.50 & 8.94 & 5.44 & 4.23 & 4.11 & $\hat{Y}=11.9523-0.1568 x$ & 71.17 \\
\hline TDM (kg/ha) & 5992.7 & $3420.2 *$ & $3694.4 *$ & $4497.4^{*}$ & $4113.8^{*}$ & $\hat{\mathrm{Y}}=2777.97+28.8371 \mathrm{x}$ & 61.95 \\
\hline ACCU (kg/ha.day) & 46.9 & $26.5 *$ & $28.7 *$ & $35.7 *$ & $33.5 *$ & $\hat{Y}=19.941+0.2787 x$ & 58.90 \\
\hline
\end{tabular}

* Statistically different from the control by Dunnett's test at 5\% probability; APRO: average forage production; \%LEA: percentage of leaves; \%STA: stalk percentage; \%DEA: percentage of dead material; LSR: leaf/steam ratio; TDM: total dry mass; ACCU: forage accumulation.

The percentage of leaves (\%LEA) of the treatments evaluated in the SPS did not differ from the control, even in the different distance from the trees (Table 1). This is probably due to the defoliation strategy adopted. When harvesting the upper half of the canopy, regardless of predefoliation height, the participation of the leaves is optimized, as reported in previous studies (Molan, 2004; Zanini et al., 2012a, 2012b). The average \%LEA of the experiment was $77.62 \%$, a value that can be considered high and indicates that the defoliation goals adopted are capable of partially achieve the goal with the pasture management, which was to increase the participation of leaves in the composition of the forage (Santos et al., 2011). This goal must be followed because the leaves are more nutritive than the stems (Freitas et al., 2012) and it facilitates the forage intake (Fonseca et al., 2012).

There was no interaction between management height and distance from trees for \%LEA, nor adjustment to the regression models studied. The absence of difference was not expected, since there was variation in the other morphological components of the forage (stems and dead material). There was a significant difference between treatments in SPS and the control for stem percentage (\% STE). Only the management goal of $55 \mathrm{~cm}$ at $5 \mathrm{~m}$ from the trees differ from the control (Table 1). This may be due to an increase in the residue height in all treatments. Zanini et al. (2012a) showed that about $90 \%$ of the stalk proportion is located below $50 \%$ of the pregrazing height. In addition, the region at a distance of $5.0 \mathrm{~m}$ from the trees is positioned in the center of the plot, where the light incidence is greater and has contributed to the further development of the forage canopy.

A positive linear response was observed on the \% STE when evaluating the effect of management heights within the SPS, regardless of the distance from the trees (Table 2). The size and advanced age of the trees (about 10 years) may have maximized the shading in the SPS in all treatments. Plants subjected to shading tend to elongate stems to expand their structure and, consequently, the interception of light by the canopy (Martins et al., 2014). Therefore, it is consistent that the increase in the management heights resulted in a higher proportion of stems at 
$55 \mathrm{~cm}$ and $5 \mathrm{~m}$ away from the trees. The percentage of dead material (\% DEA) of the treatments within the SPS did not differ from the control, even at different distances (Table 1).

However, when analyzing the \% DEA of the pastures managed at $25 \mathrm{~cm}$ in the SPS, it is observed that there was a higher proportion of dead material at $2.5 \mathrm{~m}$ than at $5.0 \mathrm{~m}$ of distance from the trees. Probably the proximity of the trees resulted in greater shading and competition, which increased the plant senescence. The regression of \% DEA as a function of management heights was significant, with adjustment to the linear model, regardless of the distance from the trees (Table 2). The increase in the management height resulted in a lower \% DEA in the harvested forage.

This is probably due to the distance from the ground. Carvalho et al. (2017) found $18.17 \%$ of $\%$ DEA when the residue was $30 \mathrm{~cm}$ and $14.50 \%$ when the post grazing height was raised to $50 \mathrm{~cm}$. The concentration of dead material near the soil favored the participation of this component in the lowest management goals. Molan (2004) observed a high proportion of green leaves in the upper strata of Marandu palisade grass and high concentration of dead material in the lower parts. In \% DEA there is also an isolated effect of the trees distance (Table 3 ). The forage at $2.5 \mathrm{~m}$ had more senescent forage than at $5.0 \mathrm{~m}$. The difference could be associated to the higher competition and shading near the trees.

Table 3. Rate of forage accumulation and percentage of dead material of palisade grass cv. Marandu at different distances from trees in silvopastoral system

\begin{tabular}{lccc}
\multicolumn{1}{c}{ Variable } & Control & \multicolumn{2}{c}{$\begin{array}{c}\text { Distance from } \\
\text { trees }(\mathrm{m})\end{array}$} \\
\cline { 3 - 4 } & & 2.5 & 5.0 \\
\hline $\begin{array}{l}\text { Percentage of dead } \\
(\%)\end{array}$ & 4.5 & $4.90 \mathrm{a}$ & $2.19 \mathrm{~b}$ \\
$\begin{array}{l}\text { Forage accumulation } \\
\text { (kg/ha.day) }\end{array}$ & 46.9 & $29.1 \mathrm{~b}^{*}$ & $33.0 \mathrm{a}^{*}$ \\
\hline
\end{tabular}

*Statistically different from the control by Dunnett's test at 5\% probability; Means followed by the same lowercase letter on the line do not differ by Tukey's test at $5 \%$ probability.

There was no significant difference in the leaf/stem ratio (LSR) between the monoculture and the shaded treatments, and there was no effect of the distances in relation to the trees (Table1). The absence of a significant difference between common and monoculture treatments may be related to the increase in defoliation targets, which harvested the upper part of the canopy with a greater participation of leaves (Molan, 2004), in all treatments. According to Fonseca et al. (2012) when animals exceed height between 40 and $50 \%$ of the pre-defoliation target (intense grazing), there is a linear drop in forage intake, which can be explained by the greater presence of stems. Thus, the defoliation targets adopted were able to provide satisfactory LSR levels to the animals. On the other hand, Rodrigues et al. (2018) observed a significant difference for LSR between SPS and monoculture and between different distances from the tree line. The authors reported that Marandu grass showed higher values for LSR in SPS (1.32) than in full sun (1.13) and a higher LSR at $2.5 \mathrm{~m}$ from the tree line than at $5.0 \mathrm{~m}$, attributing the highest value to the intense shading in that region. Despite the difference, Rodrigues et al. (2018) evaluated the LSR in the forage mass harvested at ground, which is a different methodology from that which evaluates only the grazable horizon.

Despite the absence of difference between the monoculture and the SPS, the regression of the LSR as a function of the management heights within the SPS was significant and adjusted to the linear model (Table2). There was a reduction of almost $60 \%$ in the value of the LSR with the increase in the management height. The long interval between cuts in the treatments harvested with greater heights made the canopy to be kept in free growth for a longer period. The maturity resulting from the long growth period increases stem elongation rates (Paciullo et al., 2008; Martins et al., 2014). This fact may explain the decrease in the LSR as the height of harvest of Marandu palisade grass in the SPS increased. It may represent a disadvantage for the quality of the pasture offered to the animals.

The production of total dry mass (TDM) of the monoculture differed from the treatments in the SPS regardless of the distance from the trees (Table1). The control average $(5992.7 \mathrm{~kg} / \mathrm{ha})$ was $52.12 \%$ higher than the average of the SPS (3931.4kg/ha). In fact, $\mathrm{C}_{4}$ plants such as Urochloa brizantha cv. Marandu have a high demand for light and temperature, factors that may have been limiting in the SPS. For TDM, the effect of different distances from the tree line on the SPS 
was also observed at $25 \mathrm{~cm}$. Probably the defoliation at $25 \mathrm{~cm}$ in the SPS was very severe for Marandu palisade grass, which showed a great reduction in the TDM at $2.5 \mathrm{~m}$. This effect may have been enhanced by the high shading at $2.5 \mathrm{~m}$ from the trees.

The regression of TDM in function of the management heights in the SPS showed adjustment to the growing linear model (Table2). Thus, an increase of $24.72 \%$ in biomass production was estimated between treatments with 25 and $55 \mathrm{~cm}$ in the SPS. This increase may be related to the greater light interception capacity of the highest managed pastures. According to Dim et al. (2015), the increase in the management height implies a greater amount of biomass offered in the grazable horizon, which may explain the relationship between the increase in the defoliation height and the elevation of TDM in the SPS. Despite this, the pastures in the SPS were not able to provide levels of TDM similar to the control.

Leaf dry mass (LDM) followed the same trend as TDM, and the control was statistically superior $(62.39 \%)$ to treatments in SPS, regardless of the distance from the trees. There was also a significant difference between tree distances in the goal of $25 \mathrm{~cm}$, where LDM at $2.5 \mathrm{~m}$ from the trees was lower, suggesting that this management height may have been critical for plants, reflecting low leaf productivity. There was no adjustment for this variable to the regression models studied. This may be a consequence of the increase in postgrazing heights in all treatments. On the other hand, the increase in management height was characterized by an increase in \% STE and a decrease in \% DEA, which may have contributed to the constant value of LDM.

The rate of forage accumulation (ACCU) in monoculture was significantly different from treatments in SPS, with a value 50.94\% higher than the average of intercropped treatments (Table1). There was a significant effect of the different distances of the trees. Only in the target of $25 \mathrm{~cm}$ in SPS the ACCU was lower at $2.5 \mathrm{~m}$ (Table1). It was also observed an isolated effect of the tree distances for ACCU, which was $13.40 \%$ greater at $5.0 \mathrm{~m}$ than at $2.5 \mathrm{~m}$ (Table 3 ). This result indicates that this condition of defoliation and proximity to the trees may have been harmful to the forage plant, which reduced
ACCU due to the more intense shading. According to Lopes et al. (2017b) the ACCU of signal grass cv. Basilisk can be limited in conditions of intense shading.

The ACCU was also adjusted to the linear regression model in function of the management heights in the SPS. The highest ACCU values were found at $55 \mathrm{~cm}$, the highest level of management in the present study. The difference observed between the forage accumulation of treatments with 25 and $55 \mathrm{~cm}$ in the SPS was $31.06 \%$. There was a significant difference for the variable bulk density of forage (DENS), where monoculture was superior to common SPS treatments (Table1). This is due to structural changes in the forage canopy in response to shading (Paciullo et al., 2008; Martins et al., 2014), which tends to elongate its structure.

The lack of significance between the different distances can be attributed to the robust size and advanced age of the trees, which together with the small spacing adopted, may have restricted the incident light even in the central region of the plots (5.0m away). The reduction in DENS has been observed in some studies (Santos et al., 2010a, Santos et al., 2016; Lopes et al., 2017a) and can affect forage intake by grazing animals. Nantes et al. (2013) showed lower animal weight gain per area in pastures of Urochloa brizantha cv. Piatã as the management goal increased, reducing the canopy volumetric density.

There was a significant difference between common treatments and the control and significant interaction between management heights and distance from trees within the SPS for number of tillers (NTIL). The NTIL of treatments with 25 and $35 \mathrm{~cm}$ in the SPS was lower than the control, regardless of the distance from the trees. In the treatment with $55 \mathrm{~cm}$, this difference was only observed at $5.0 \mathrm{~m}$ from the trees. Thus, the NTIL of treatments with 45 at both distances and $55 \mathrm{~cm}$ at a distance of $2.5 \mathrm{~m}$ did not differ from the control (Table4).

In view of the significant interaction, the NTIL regression as a function of management heights was studied separately for each distance from the trees (Table 4). At a distance of $2.5 \mathrm{~m}$, NTIL adjusted to the linear regression model (Table 4). There was an increase in NTIL as the management height increased. This fact was not observed by Rodrigues et al. (2018), in Urochloa brizantha 
pastures defoliated at 2.5 and $5.0 \mathrm{~m}$ from trees. The authors did not observe a significant difference in the number of tillers between the different harvesting distances.

The results observed in the present study are not in agreement with the theory of compensation between size and tiller density already consolidated for Urochloa pastures managed in full sun (Sbrissia and Silva, 2008). The elevation of residue height with the management goal may have left a high number of buds in the highest residues. These buds may

Table 4. Tiller density of Marandu grass in monoculture (Contr.) and in silvopastoral system (SPS) under 4 defoliation heights and at two distances (Dist.) from the trees

\begin{tabular}{|c|c|c|c|c|c|c|c|c|c|}
\hline \multirow{2}{*}{ Variable } & \multirow[b]{2}{*}{ Contr. } & \multirow{2}{*}{ Dist. (m) } & \multicolumn{4}{|c|}{ Management heights in SPS $(\mathrm{cm})$} & \multirow{2}{*}{ Regression equation } & \multirow{2}{*}{$\mathrm{R}^{2}$} & \multirow{2}{*}{$\mathrm{CV}(\%)$} \\
\hline & & & 25 & 35 & 45 & 55 & & & \\
\hline \multirow{2}{*}{ Tillers } & \multirow{2}{*}{676.2} & 2.5 & $455.6 a^{*}$ & $494.7 a^{*}$ & $598.7 \mathrm{a}$ & $621.3 \mathrm{a}$ & $\hat{\mathrm{Y}}=265.015+4.8790 \mathrm{x}$ & 93.72 & \multirow{2}{*}{10.30} \\
\hline & & 5.0 & $516.8 a^{*}$ & $535.9 \mathrm{a}^{*}$ & $595.6 \mathrm{a}$ & $488.0 b^{*}$ & $\hat{Y}=575.9$ & - & \\
\hline
\end{tabular}

* Statistically different from the control by Dunnett's test at 5\% probability; Means followed by lowercase letters in the column do not differ by Tukey's test at $5 \%$ probability.

have been developed due to their higher position in the canopy and compensated the shading effect of the trees, which in this region $(2.5 \mathrm{~m})$ was more intense. Thus, the increase in tillering with the management height increase at $2.5 \mathrm{~m}$ distance was mainly due to the aerial tillering of Marandu palisade grass in the highest defoliated pastures and, consequently, with greater residue.

On the other hand, at 5.0m, NTIL did not fit the studied regression models, with an average of 575.9 tillers $/ \mathrm{m}^{2}$. Santos et al. (2001), working with elephant grass, also observed an increase in aerial tillering as the height of the forage harvest increased. However, more studies are necessary to better understand aerial tillering in SPS. Aerial tillering can represent an important productive source for forage. Santos et al. (2010b) state that aerial tillering increases the leaf area of basal tillering by $76 \%$ in $U$. decumbens pastures, which increases the light interception of the forage canopy.

The height that provides the best response among the management goals in SPS $(55 \mathrm{~cm})$ was considered the one that came closest to monoculture. Based on this premise, the hypothesis that the height at $95 \%$ of LI is modified by silvopastoral conditions has been confirmed. On the other hand, the morphological composition and the leaf/stem ratio were not influenced by the cultivation system. The hypothesis that the distance from trees can affect the accumulation of forage was also confirmed. In addition, the reduction in the \% DEA also shows that the hypothesis of modification of the morphological composition by the distance from the trees was partially confirmed. The manifestation of differences in morphological and production terms was evident in plants managed with $25 \mathrm{~cm}$ in the $\mathrm{SPS}$, where parameters such as ACUM and LDM and \% DEA were worse in the region closest to the trees.

\section{CONCLUSION}

The monoculture of Marandu palisade grass results in better forage accumulation, leaf drymass and bulky density than in silvopastoral system, regardless of the management goal. The proximity of the trees in the SPS reduces the forage accumulation of Marandu palisade grass. The $55 \mathrm{~cm}$ target was characterized by greater production of forage biomass and greater accumulation, being the recommended height for management of Marandu palisade grass in SPS.

\section{ACKNOWLEDGEMENTS}

The authors thank Fundação de Amparo à Pesquisa do Estado de Minas Gerais (Fapemig) for supporting this research. 


\section{REFERENCES}

BERNARDINO, F.S.; GARCIA, R. Sistemas silvipastoris. Pesqui. Florest. Bras., n.60, p.7787, 2009. (Edição especial).

CARVALHO, A.L.S.; MARTUSCELLO, J.A.; ALMEIDA, O.G.; BRAZ, T.G.S. et al. Production and quality ofmombaça grass forage under different residual heights. Acta Sci. Anim. Sci., v.39, p.143-148, 2017.

CRUZ, C.D. Genes: a software package for analysis in experimental statistics and quantitative genetics. Acta. Sci. Agron., v.35, p.271-276, 2013.

FREITAS, F.P.; FONSECA, D.M.; BRAZ, T.G.S.; MARTUSCELLO, J.A. et al. Forage yield and nutritive value of Tanzania grass under nitrogen supplies and plant densities. Rev. Bras. Zootec., v.41, p.864-872, 2012.

GIACOMINI, A.A.; SILVA, S.C.; SARMENTO, D.O.L.; ZEFERINO, C.V. et al. Growth of marandu palisade grass subjected to strategies of intermitent stocking. Sci. Agric., v.66, p.733-741, 2009.

LOPES, C.M.; PACIULLO, D.S.C.; ARAÚJO, S.A.C.; GOMIDE, C.A.M. et al. Massa de forragem, composição morfológica e valor nutritivo de capim-braquiária submetido a níveis de sombreamento e fertilização. Arq. Bras. Med. Vet. Zootec., v.69, p.225-233, 2017a.

LOPES, C.M.; PACIULLO, D.S.C.; ARAÚJO, S.A.C.; MORENZ, M.J.F. et al. Plant morphology and herbage accumulation of signal grass with or without fertilization, under different light regimes. Ciênc. Rural, v.47, p.1-7, $2017 \mathrm{~b}$.

MARTINS, A.D.; SOUSA, L.F.; NÓBREGA, E.B.; DONIZETTI, J.G.S. et al. Relação do nível de sombreamento artificial e da adubação sobre o desenvolvimento da forrageira Urochloa brizantha cv. marandu. Rev. Bras. Saúde Prod. Anim., v.15, p.994-1005, 2014.

MOLAN, L.K. Estrutura do dossel, interceptação luminosa e acúmulo de forragem em pastos de capim-marandu submetidos a alturas de pastejo por meio de lotação contínua. 2004. 159f. Dissertação (Mestrado em Agronomia) Universidade de São Paulo. Piracicaba, SP.
MONTAGNER, D.B.; EUCLIDES, V.P.B.; GENRO, T.C.M.; NATES, N.N. Drymatter intake by beef steers on Piatã palisadegrass (Brachiaria brizantha cv. BRS Piatã) pasture. Trop. Grassl. Forrajes Trop., v.1, p.106-108, 2013.

NANTES, N.N.; EUCLIDES, V.P.B.; MONTAGNER, D.B.; LEMPP, B. et al. Desempenho animal e características de pastos de capim-piatã submetidos a diferentes intensidades de pastejo. Pesqui. Agropecu. Bras., v.48, p.114121, 2013.

PACIULLO, D.S.C.; CARVALHO, C.A.B.; AROEIRA, L.J.M.; MORENZ, M.J.F. et al. Morfofisiologia e valor nutritivo do capimbraquiária sob sombreamento natural e a sol pleno. Pesqui. Agropecu. Bras., v.42, p.573-579, 2007.

PACIULLO, D.S.C.; CAMPOS, N.R.; GOMIDE, C.A.M.; CASTRO, C.R.T. et al. Crescimento de capim-braquiária influenciado pelo grau de sombreamento e pela estação do ano. Pesqui. Agropecu. Bras., v.43, p.917-923, 2008.

RODRIGUES, B.M.; BRAZ, T.G.S.; FRAZÃO, L.A.; ALMEIDA, B.Q. et al. Consorciação de estilos antes campo grande e capim-marandu em sistema silvipastoril e sol pleno durante a fase de estabelecimento. Bol. Ind. Anim., v.75, p.1-11, 2018.

SANTOS, D.C.; GUIMARÃES JÚNIOR, F.; VILELA, L.; PULROLNIK, K. et al. Forage dry mass accumulation and structural characteristics of Piatã grass in silvopastoral systems in the Brazilian savannah. Agric. Ecosyst. Environ., v.233, p.16-24, 2016.

SANTOS, E.A.; SILVA, D.S.; QUEIROZ FILHO, J.L. Perfilhamento e algumas características morfológicas do capim-elefante cv. roxo sob quatro alturas de corte em duas épocas do ano. Rev. Bras. Zootec., v.30, p.24-30, 2001.

SANTOS, M.E.R.; FONSECA, D.M.; BRAZ, T.G.S.; SILVA, S.P. et al. Características morfogênicas e estruturais de perfilhos de capimbraquiária em locais do pasto com alturas variáveis. Rev. Bras. Zootec., v.40, p.535-542, 2011. 
SANTOS, M.E.R.; FONSECA, D.M.; GOMES, V.M.; SILVA, S.P. et al. Morfologia de perfilhos basais e aéreos em pasto de Brachiaria decumbens manejado em lotação contínua. Encicl. Biosf., v.6, n.9, 2010 b.

SANTOS, M.E.R.; FONSECA, D.M.; SILVA, G.P.; PIMENTEL, R.M. et al. Estrutura do pasto de capim-braquiária com variação de alturas. Rev. Bras. Zootec., v.39, p.2125-2131, 2010a.

SBRISSIA, A.F.; SILVA, S.C. Compensação tamanho/densidade populacional de perfilhos em pastos de capim-marandu. Rev. Bras. Zootec., v.37, p.35-47, 2008.
ZANINI, G.D.; SANTOS, G.T.; SCHMITT, D.; PADILHA, D.A. et al. Distribuição de colmo na estrutura vertical de pastos de capim Aruana e azevém anual submetidos a pastejo intermitente por ovinos. Ciênc. Rural, v.42, p.882-887, 2012a.

ZANINI, G.D.; SANTOS, G.T.; SBRISSIA, A.F. Frequencies and intensities of defoliation in Aruana Guineagrass swards: accumulation and morphological composition of forage. Rev. Bras. Zootec., v.41, p.905-913, 2012 b. 